\title{
COMPARISON OF SOME PROPERTIES OF PRONETHALOL AND PROPRANOLOL
}

\author{
BY \\ J. W. BLACK,* W. A. M. DUNCAN* AND R. G. SHANKS \\ From Imperial Chemical Industries Ltd., Pharmaceuticals Division, Research Department, \\ Alderley Park, Macclesfield, Cheshire
}

(Received January 27, 1965)

\begin{abstract}
Much evidence has accumulated to justify the classification of pronethalol (Alderlin ; I.C.I.) as a sympathetic $\beta$-receptor antagonist described in terms of Ahlquist's (1948) dualreceptor hypothesis. There has now been confirmation in animal experiments of antagonism to adrenergically induced vasodilatation (Ahlquist, 1963 ; Abboud, Eckstein \& Zimmerman, 1963), cardiac stimulation (Meester, Hardman \& Barboriak, 1963 ; Kako, Krayenbühl, Lüthy \& Hegglin, 1964 ; Donald, Kvale \& Shepherd, 1964), bronchodilatation (Nagasaka, Schaepdryver \& Heymans, 1964), uterine relaxation (Levy \& Tozzi, 1963) and gut relaxation after block or loss of $\alpha$-receptors (Lum \& Kermani, 1963). In human pharmacological studies antagonism to catecholamine-induced vasodilatation and cardiac stimulation (Dornhorst \& Robinson, 1962 ; Lowe \& Robinson, 1964) has been reported. Reduction of exercise tachycardia in man has been described by Bishop \& Segel (1963), Chamberlain \& Howard (1964), Harrison, Braunwald, Glick, Mason, Chidsey \& Ross (1964) and Schröder \& Werkö (1964).
\end{abstract}

The effects of pronethalol in experimental cardiac arrhythmias in dogs and guinea-pigs have been investigated. Antagonism of arrhythmias induced by cardiac glycosides has been reported by Erlij \& Mendes (1964), Vaughan-Williams \& Sekiya (1963) and Somani, Hardman \& Lum (1963). Prevention of arrhythmias induced by adrenaline during anaesthesia with a hydrocarbon has been found by Murray, McKnight \& Davis (1963) and by Hess \& Hampton (1964). Somani et al. (1963) have shown that pronethalol will block ectopic ventricular tachycardia produced by large doses of adrenaline, and Ehringer \& Gögel (1963) claim that it reduces the apical myocardial necrosis produced in rats by large doses of isoprenaline.

This interest in the cardiovascular actions of pronethalol is also shown in various clinical reports. Success in the treatment of some cardiac arrhythmias, including digitalis intoxication, has been reported by Stock \& Dale (1963) and Grandjean \& Rivier (1963). Encouraging results in the treatment of angina have been found in a multicentre doubleblind trial (Alleyne, Dickinson, Dornhorst, Fulton, Green, Hill, Hurst, Laurence, Pilkington, Prichard, Robinson \& Rosenheim, 1963) and in a small, placebo-controlled, trial of effort tolerance (Apthorp, Chamberlain \& Hayward, 1964). Potential therapeutic value of pronethalol in the management of phaeochromocytoma (Dornhorst \& Laurence, 1963)

*Present address: Smith Kline \& French Limited, Welwyn Garden City, Herts. 
and hypertrophic obstructive cardiomyopathy (Harrison et al., 1964; Cohen, Effat, Goodwin, Oakley \& Steiner, 1964) has been described. Effective treatment of ventricular arrhythmias occurring during halothane anaesthesia has been reported by Johnstone (1964) and by Payne \& Senfield (1964). These reports confirm the suggestions by Black $\&$ Stephenson (1962) that sympathetic $\beta$-receptor antagonists might be valuable in the study and treatment of certain cardiac disorders.

The overt toxic effects of pronethalol described by Black \& Stephenson (1962) were tremors and convulsions. These signs were correlated with the evidence that the brain concentrations of pronethalol were of the order of 100-times the blood concentration. The acute toxic signs appeared at doses seven- to ten-times greater than those needed for effective $\beta$-receptor blockade. While tremors and convulsions have not been described in man, effective doses are often associated with unpleasant subjective side-effects. Mild disorientation, slight inco-ordination, nausea and vomiting have been described (Alleyne et al., 1963). Since the toxic signs in animals are seen with the inactive $(+)$-isomer as as well as with the active (-)-isomers (Howe, 1963), it has been assumed that the effects of pronethalol on the central nervous system are probably not due to $\beta$-receptor blockade. A more serious toxic manifestation was found in mice. Studies showed that pronethalol was a moderately potent carcinogen in this species. Malignant tumours, mainly thymic lymphosarcomata, began to appear after 10 weeks continuous dosing (Paget, 1963; Alcock \& Bond, 1964).

This combination of nonspecific central actions and carcinogenic potential in a compound of clinical interest put a premium on finding a less toxic compound. A preliminary communication (Black, Crowther, Shanks, Smith \& Dornhorst, 1964) on such a compound has been published; this compound is propranolol (Inderal ; I.C.I.). The relationship of propranolol to pronethalol is shown by the structural formulae:

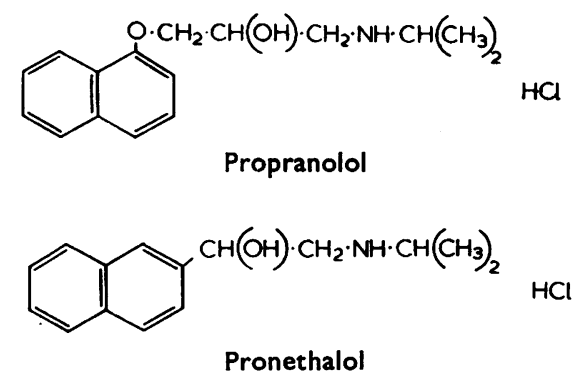

This paper presents details of the comparative activity of these compounds. Detailed studies of their toxicity by our colleagues have shown that daily treatment of mice with propranolol over a period of $\mathbf{1 8}$ months did not produce thymic tumours (Alcock, Baker \& Tucker, 1965).

\section{METHODS}

\section{Contraction rates of isolated right atrial strips}

Guinea-pigs, weighing between 620 and $1,000 \mathrm{~g}$, were killed by stunning. The heart was immediately exposed and a ligature was tied around the anterior vena cava. A second, pinch, ligature was tied on the wall of the right atrium close to the atrio-ventricular groove. A narrow strip of atrium between the ligatures, including the sinoatrial node, was then excised. The muscle 
strip was attached to a strain-gauge transducer and placed in a $10 \mathrm{ml}$. organ-bath filled with a buffered solution (McEwen, 1956) at $37.5^{\circ} \mathrm{C}$ which was gassed with $95 \%$ oxygen and $5 \%$ carbon dioxide. The output from the transducer was used to drive a ratemeter. The spontaneous contraction rate of the muscle could be read on the meter to the nearest 5 beats/min and simultaneously recorded on a kymograph by a moving-coil oscillograph.

The preparation was left for 30 min or until a steady contraction rate had been reached. Cumulative dose/response curves for adrenaline were recorded by adding adrenaline to the bath from a micrometer syringe in geometrically increasing doses without changing the bath fluid. Each succeeding dose of adrenaline was added to the bath after the maximum response to the previous dose had been reached. At the end of the dose/response titration the bath fluid was changed repeatedly until a steady control rate of contraction was reached once more. A series of dose/response curves in the presence of various doses of antagonist were recorded for calculation of $p A_{2}$ values by the method of Schild (1947).

\section{Heart rates in anaesthetized cats}

Cats weighing between 2 and $3.5 \mathrm{~kg}$ were anaesthetized with chloralose, $80 \mathrm{mg} / \mathrm{kg}$, given intravenously. Spontaneous breathing was assisted by insertion of a tracheal cannula. Femoral arterial pressure was measured with a mercury manometer and heart rate by means of a cardiotachometer triggered by the QRS complex of the electrocardiogram; both measurements were recorded on a kymograph. Femoral veins were cannulated for injection of drugs. The right stellate ganglion was approached from the back by removal of part of the second rib, so that the pleural cavity was not opened. Miniature shielded bipolar electrodes were applied to the distal ends of both the right cardioaccelerator nerves and the right vagus nerve.

\section{Blood pressure and ventricular isometric tension in anaesthetized dogs}

Dogs were anaesthetized with intravenous pentobarbitone, $40-50 \mathrm{mg} / \mathrm{kg}$. The chest was opened through the fourth left intercostal space and the lungs were artificially ventilated. A strain-gauge arch (Cotten, 1953) was sutured to the left ventricle near its apex and arterial pressure was recorded from a cannula in the left carotid artery with an inductive-type differential-pressure transducer (New Electronic Products Ltd). Drugs were injected through a catheter in a foreleg vein.

\section{Observations on conscious animals}

Observations were made on dogs and rabbits. Heart rate was measured by a cardiotachometer, using fine needle electrodes inserted under the skin; drugs were injected through fine indwelling catheters in veins in the ear.

\section{Estimations of pronethalol and propanolol in blood and tissues}

Tissue samples $(2 \mathrm{~g})$ were homogenized in $10 \mathrm{ml}$. of a $\mathrm{pH} 10.2$ universal buffer (Davies, 1959) and aliquots $(2 \mathrm{ml}$.) of the homogenate were extracted with $1 \%$ ethanol in $n$-heptane $(12 \mathrm{ml}$.$) . The$ drug was extracted from the organic phase $(10 \mathrm{ml}$.) into $8.1 \mathrm{~N}$-hydrochloric acid $(1.2 \mathrm{ml}$.$) and the$ fluorescence of the acid extract was measured at $350 \mathrm{~m} \mu$ (uncorrected) with activation at $280 \mathrm{~m} \mu$ (uncorrected); the concentration of the drug in the sample was determined by carrying known amounts of drug through the extraction procedure. To blood samples $(2 \mathrm{ml}$.) was added $1 \%$ ethanol in $n$-heptane $(12 \mathrm{ml}$.) and aqueous $0.1 \mathrm{~N}$-sodium hydroxide solution $(1 \mathrm{ml}$.); the extraction procedure and estimation were then identical with those described above. Tissue blanks were determined for a range of tissues and were equivalent to 0.005 or $0.006 \mu \mathrm{g}$ of pronethalol or propranolol per $\mathrm{g}$ of tissue. Blood blanks contained amounts equivalent to 0.004 to $0.005 \mu \mathrm{g} / \mathrm{ml}$. Recoveries of both compounds from a range of tissues were $55 \pm 8 \%$, and from blood $80 \pm 5 \%$. The reliability of the method for tissue concentrations from 0.01 to $1.0 \mu \mathrm{g} / \mathrm{g}$ was $\pm 10 \%$ and for blood concentrations from 0.01 to $2.0 \mu \mathrm{g} / \mathrm{ml}$. was $\pm 10 \%$.

The following drugs were used: (-)-adrenaline bitartrate (Burroughs Wellcome); ( \pm )-isoprenaline sulphate (Burroughs Wellcome); (-)-noradrenaline bitartrate (Winthrop); histamine acid phosphate (B.D.H.) ; acetylcholine chloride (Roche); ( \pm )-pronethalol hydrochloride ; ( \pm )-propranolol hydro- 
chloride. These were dissolved in $0.9 \%$ saline; concentrations are expressed in terms of the salt per unit volume.

\section{RESULTS}

Effects of pronethalol and propranolol on contraction rate of atrial muscle in vitro

In nine experiments right atrial strips had a control contraction rate of $202 \pm 7.7$ beats/ min at $37.5^{\circ} \mathrm{C}$ (mean and standard error). Cumulative adrenaline dose/response curves produced a final maximum mean contraction rate of $326 \pm 7.1$ beats $/ \mathrm{min}$. In constructing the dose/response curves in Fig. 1, increments in contraction rate are expressed as percentages of the maximum rate. The results shown in Fig. 1,a are the means of four experiments and show the antagonistic effects of increasing doses of propranolol. The results of a similar series of four experiments with pronethalol are shown in Fig. 1,b.

The parallel shift to the right in the dose/response curves is characteristic of competitive antagonists. From a comparison of the doses of adrenaline and antagonist required to produce $50 \%$ of the maximum increase in contraction rate, $p A_{2}$ values were calculated. The results are given in Table 1.

(a) Propranolol

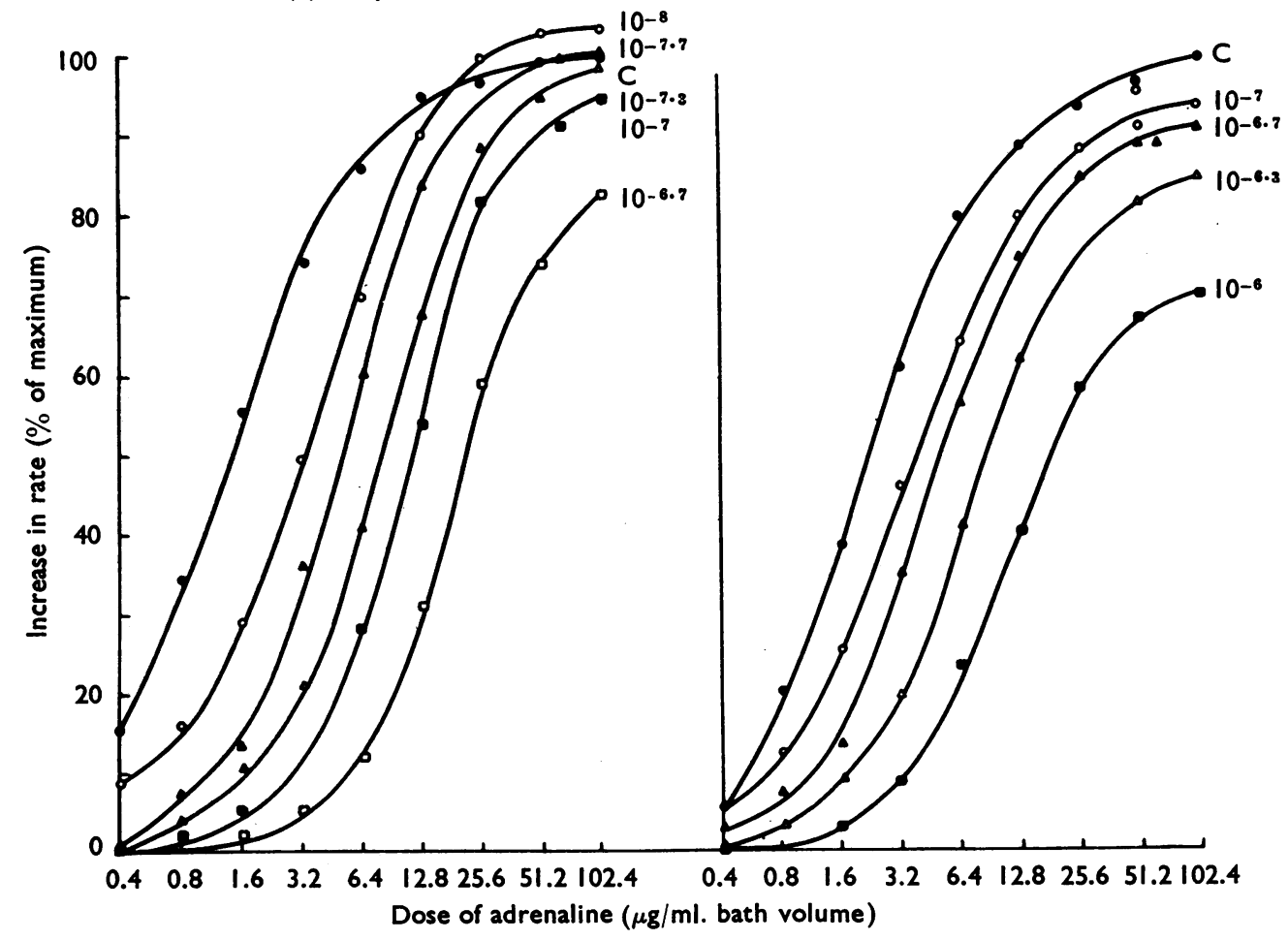

Fig. 1. Guinea-pig right atrial strip suspended in McEwen solution. Increases in contraction rate are expressed as a percentage of the maximum rate produced by the addition of geometrically increasing doses of adrenaline to the bath. (a) After obtaining control responses, propranolol was added to the bath to give concentrations of $10^{-8}, 10^{-9.7}, 10^{-7.8}, 10^{-7.0}$ and $10^{-6.7} \mathrm{~g} / \mathrm{ml}$. (b) Pronethalol was added to give concentrations of $10-7.0,10-67,10-68$ and $10-6.0 \mathrm{~g} / \mathrm{ml}$. 
TABLE 1

INDIVIDUAL $p A_{2}$ VALUES FOR PROPRANOLOL AND PRONETHALOL FROM EXPERIMENTS ON ATRIAL STRIPS

\begin{tabular}{cc}
\multicolumn{2}{c}{$p A_{2}$ values for } \\
\hline Propranolol & Pronethalol \\
$7 \cdot 21$ & $6 \cdot 43$ \\
$6 \cdot 68$ & $6 \cdot 19$ \\
$7 \cdot 54$ & $6 \cdot 20$ \\
$8 \cdot 60$ & $5 \cdot 83$ \\
& $6 \cdot 32$ \\
$7 \cdot 51 \pm 0.41$ & $6 \cdot 19 \pm 0 \cdot 10$
\end{tabular}

Although propranolol is significantly more active than pronethalol, there are insufficient results for calculation of accurate potency ratios. While the ratio of the mean $p A_{2}$ values is 20.9 , the $95 \%$ confidence limits are $2-208$.

\section{Effects of antagonists on changes in heart rate of anaesthetized cats}

Increases in heart rate produced by intravenous injections of isoprenaline were determined before, during and after the intravenous infusion of propranolol. A typical experiment is shown in Fig. 2. During the infusion of propranolol there was a fall in resting heart rate and a reduction in the tachycardia produced by isoprenaline. In five

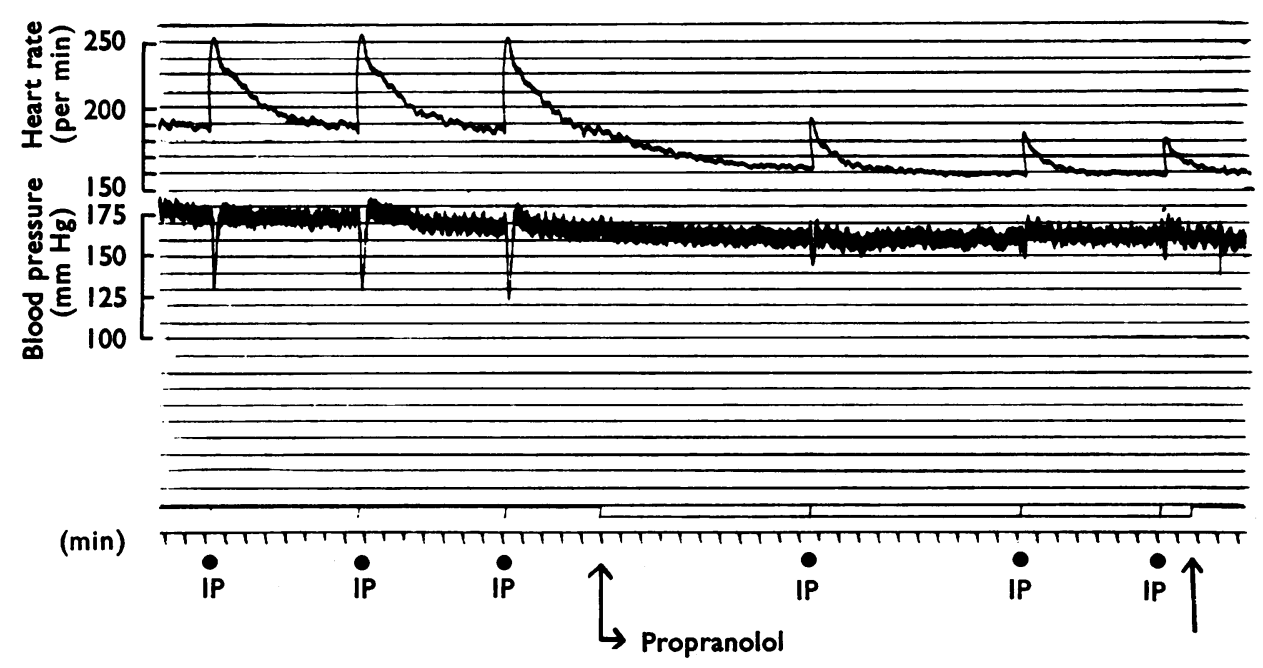

Fig. 2. Cat, chloralose anaesthesia; heart rate and femoral arterial pressure records. Responses to intravenous injections of isoprenaline (at IP; $0.2 \mu \mathrm{g} / \mathrm{kg}$ ) were obtained before and during the intravenous infusion of propranolol (between arrows; $2.5 \mu \mathrm{g} / \mathrm{kg} / \mathrm{min}$ ).

experiments, a total dose of $0.075 \mathrm{mg} / \mathrm{kg}$ of propranolol, given as $2.5 \mu \mathrm{g} / \mathrm{kg} / \mathrm{min}$ for $30 \mathrm{~min}$, produced a fall in heart rate of $11 \pm 1.8 \%$ (mean and standard error). The increases in heart rate produced by isoprenaline injections averaged $35 \pm 5.0 \%$ and were reduced by $60 \pm 8.4 \%$ after the infusion of propranolol. In other experiments an increase in heart rate was produced by the intravenous infusion of isoprenaline at $0.2 \mu \mathrm{g} / \mathrm{kg} / \mathrm{min}$ before and $30 \mathrm{~min}$ after commencing the intravenous infusion of propranolol at 1,5 and 
$25 \mu \mathrm{g} / \mathrm{kg} / \mathrm{min}$ or pronethalol at 4,20 and $100 \mu \mathrm{g} / \mathrm{kg} / \mathrm{min}$. Both drugs were administered at each dose to three cats and the averaged results are given in Fig. 3. Pronethalol produced no change in resting heart rate; a progressive bradycardia was obtained with increasing doses of propranolol. Both drugs produced an increasing blockade of the tachycardia due to isoprenaline; these results indicate that propranolol is about ten times as active as pronethalol.

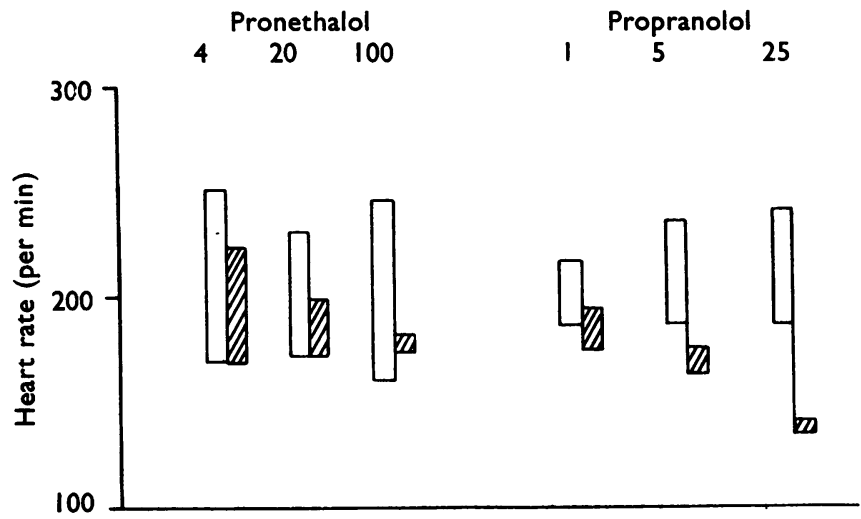

Fig. 3. Cats anaesthetized with chloralose. Open rectangles: increase in heart rate produced by the intravenous infusion of isoprenaline $(0.2 \mu \mathrm{g} / \mathrm{kg} / \mathrm{min})$; hatched rectangles: response to isoprenaline after the intravenous infusion of propranolol or pronethalol (doses in $\mu \mathrm{g} / \mathrm{kg} / \mathrm{min}$ ) for $30 \mathrm{~min}$. Each set of results is the mean of observations in three cats, the bottom of each rectangle showing the mean control value and the top of each rectangle the mean value after isoprenaline.

Further observations were made in five cats anaesthetized with chloralose $16 \mathrm{hr}$ after treatment with syrosingopine, $5 \mathrm{mg} / \mathrm{kg}$ subcutaneously. Syrosingopine is an analogue of reserpine and has been shown to deplete peripheral noradrenaline stores (Orlans, Finger \& Brodie, 1960). This action was confirmed in the present experiments by an absence of an increase in heart rate during stimulation of the left stellate ganglion and by a great reduction in the increase in heart rate produced by the intravenous injection of tyramine $(0.5 \mathrm{mg} / \mathrm{kg})$. After obtaining control responses to the intravenous infusion of isoprenaline $(0.2 \mu \mathrm{g} / \mathrm{kg} / \mathrm{min})$, propranolol was given by intravenous infusion at $25 \mu \mathrm{g} / \mathrm{kg} / \mathrm{min}$ for $30 \mathrm{~min}$ to two cats; pronethalol and dichloroisoprenaline were administered at $100 \mu \mathrm{g} /$ $\mathrm{kg} / \mathrm{min}$ to two and to one cat respectively. The results of these experiments are given in Table 2. Dichloroisoprenaline produced a marked increase in heart rate and consequently it was impossible to assess its effect on the isoprenaline tachycardia. Propranolol produced very little change in heart rate, while pronethalol increased heart rate by 26 and 22 beats/min.

The correlation between intravenous dose, blood level, and antagonism of tachycardia due to isoprenaline has been examined for both propranolol and pronethalol. Experiments on four cats were carried out for each drug. Isoprenaline was given three times during a control period and then 2 min after each administration of a series of geometrically increasing doses of propranolol $(0.005$ to $0.08 \mathrm{mg} / \mathrm{kg})$ and pronethalol $(0.05$ to $1.6 \mathrm{mg} / \mathrm{kg})$. Samples of blood $(2 \mathrm{ml}$.) were taken from a catheter in a femoral artery $1 \mathrm{~min}$ before and $1 \mathrm{~min}$ after each dose of isoprenaline. The concentration of 
TABLE 2

\section{RESULTS FOR FIVE CATS TREATED WITH SYROSINGOPINE (5 MG/KG, SUBCUTANEOUSLY)} AND ANAESTHETIZED WITH CHLORALOSE

Resting heart rate and the increase in heart rate produced by the intravenous infusion of isoprenaline $(0.2 \mu \mathrm{g} / \mathrm{kg} / \mathrm{min})$ were recorded before and at the end of the intravenous infusion for $30 \mathrm{~min}$ of propranolol, pronethalol and dichloroisoprenaline. Control: observations during control period. Test: observations after the intravenous infusion of the compound for $30 \mathrm{~min}$

\begin{tabular}{|c|c|c|c|c|c|}
\hline \multirow[b]{2}{*}{ Drug } & \multirow{2}{*}{$\underset{(\mu \mathrm{g} / \mathrm{kg} / \mathrm{min})}{\text { Dose }}$} & \multicolumn{2}{|c|}{$\begin{array}{l}\text { Resting heart rate } \\
\text { (beats/min) }\end{array}$} & \multicolumn{2}{|c|}{$\begin{array}{l}\text { Isoprenaline tachycard } \\
\text { (beats/min) }\end{array}$} \\
\hline & & Control & Test & Control & Test \\
\hline Propranolol & $\begin{array}{l}25 \\
25\end{array}$ & $\begin{array}{l}160 \\
150\end{array}$ & $\begin{array}{l}162 \\
144\end{array}$ & $\begin{array}{l}83 \\
76\end{array}$ & $\begin{array}{r}6 \\
12\end{array}$ \\
\hline Pronethalol & 100 & 180 & 206 & 80 & 5 \\
\hline Dichloroisoprenaline & $\begin{array}{l}100 \\
100\end{array}$ & $\begin{array}{l}148 \\
157\end{array}$ & $\begin{array}{l}170 \\
254\end{array}$ & 80 & 6 \\
\hline
\end{tabular}

propranolol or pronethalol in each sample was determined and by extrapolation the concentration in the blood at the time the isoprenaline was given was found. The results are given in Fig. 4, in which the percentage block of the isoprenaline tachycardia is correlated with the concentration of the drug in the blood. On these results, the potency ratio of propranolol and pronethalol is approximately 10 .

Effects of antagonists on the blood pressure of anaesthetized dogs

The effects of increasing doses of propranolol on diastolic pressure and on the fall in pressure produced by isoprenaline have been tested in six anaesthetized dogs. Three

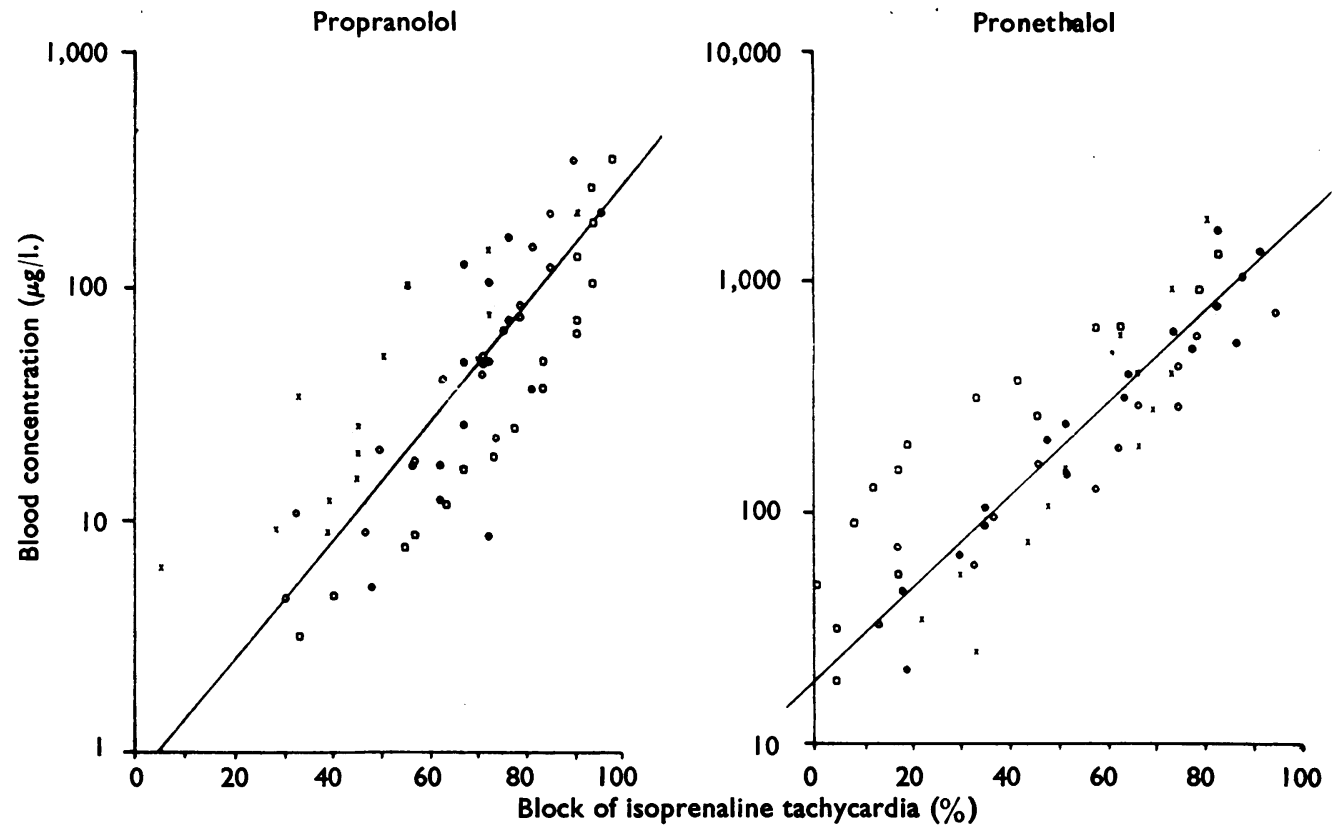

Fig. 4. Cats anaesthetized with chloralose. Correlation of the concentration of propranolol and pronethalol in arterial blood $(\mu \mathrm{g} / 1$.) with the percentage antagonism of the increase in heart rate produced by the intravenous injection of isoprenaline $(0.2 \mu \mathrm{g} / \mathrm{kg})$. Each set of symbols represents results from one cat. 
control responses to injections of isoprenaline $(0.2 \mu \mathrm{g} / \mathrm{kg})$ at 6 to $10 \mathrm{~min}$ intervals were recorded. Then $0.01 \mathrm{mg} / \mathrm{kg}$ of propranolol was given intravenously and $3 \mathrm{~min}$ later the isoprenaline was repeated. Geometrically increasing doses of propranolol to $0.16 \mathrm{mg} / \mathrm{kg}$ were given at 12 to $14 \mathrm{~min}$ intervals and the responses to isoprenaline were repeated after each dose. The averaged results are given in Fig. 5 in which the diastolic pressure and

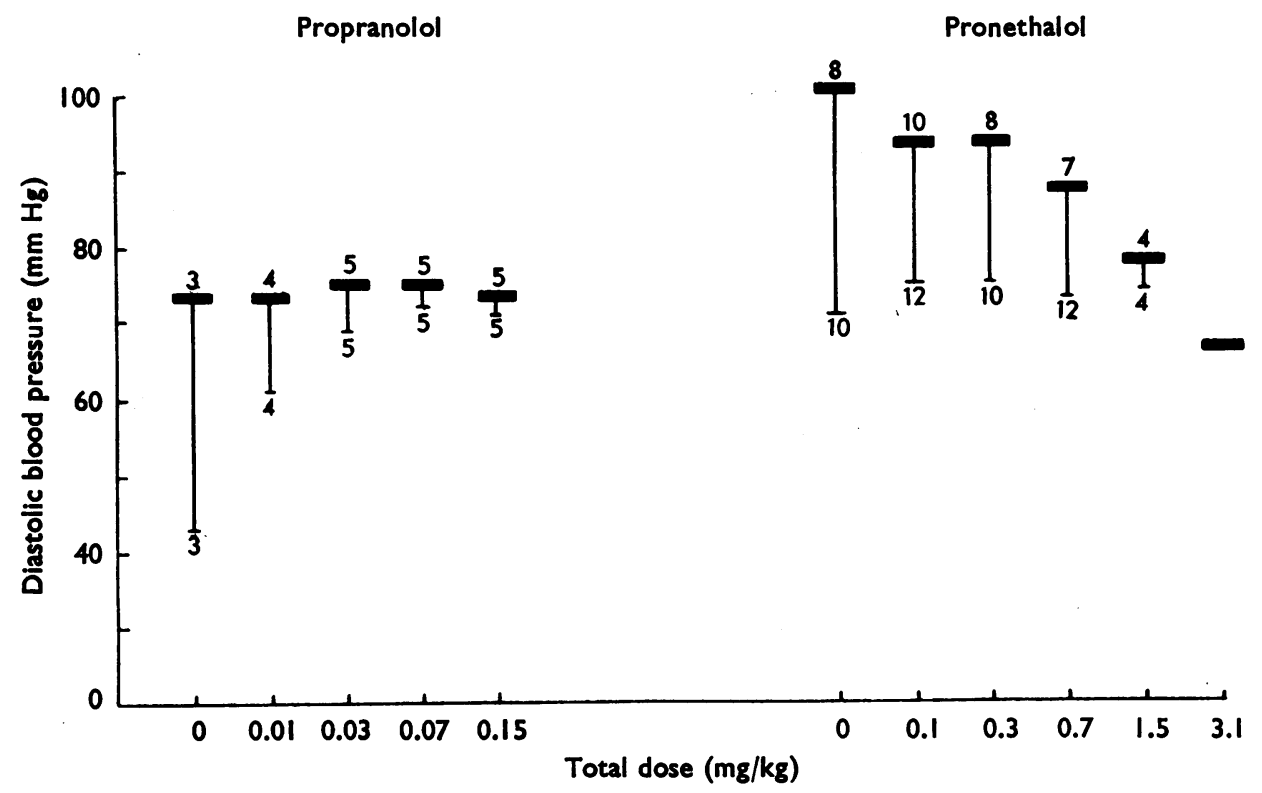

Fig. 5. Dogs anaesthetized with pentobarbitone; pressure recorded from a carotid artery. Control diastolic pressure is represented by the thick bars and the minimum pressure after the intravenous injection of $0.2 \mu \mathrm{g} / \mathrm{kg}$ of isoprenaline by the thin bars. The effect of the intravenous injection of increasing doses of propranolol and pronethalol on diastolic pressure and on the response to isoprenaline are shown. Numbers on the graphs are the standard errors.

the degree of hypotension due to isoprenaline during the control period and after the administration of pronethalol and propranolol are shown. While progressive hypotension is seen with increasing doses of pronethalol, effective blockade of isoprenaline hypotension is produced by propranolol without any fall in blood pressure. These results also show that propranolol is at least ten-times as active as pronethalol in blocking the vasodepressor action of isoprenaline. In these experiments the effects of propranolol and pronethalol on the inotropic responses to isoprenaline were also studied, and the results have been published (Black et al., 1964).

Effect of propranolol and pronethalol on the bradycardia produced by vagal stimulation

Observations were made on cats anaesthetized with chloralose. In ten experiments the effect of intravenous infusions of propranolol at both 5 and $50 \mu \mathrm{g} / \mathrm{kg} / \mathrm{min}$ on the bradycardia produced by stimulation of the peripheral end of the right vagus nerve at frequencies of $1,2,5$ and 10 shocks/sec were compared with their effect on the tachycardia produced by stimulation of the right stellate ganglion at the same rates. After 
two series of control observations had been made on each cat for both vagal and stellate stimulations propranolol was infused until the end of the experiment. After the compound had been infused for $30 \mathrm{~min}$ stimulation of the vagus and of the stellate ganglion was repeated. The results are shown in Fig. 6,a; the results of a similar series of experiments in which pronethalol was administered at 50 and $200 \mu \mathrm{g} / \mathrm{kg} / \mathrm{min}$ are given in Fig. 6,b. It can be seen that complete antagonism to sympathetic tachycardia can be produced without any reduction of vagal bradycardia by both compounds.

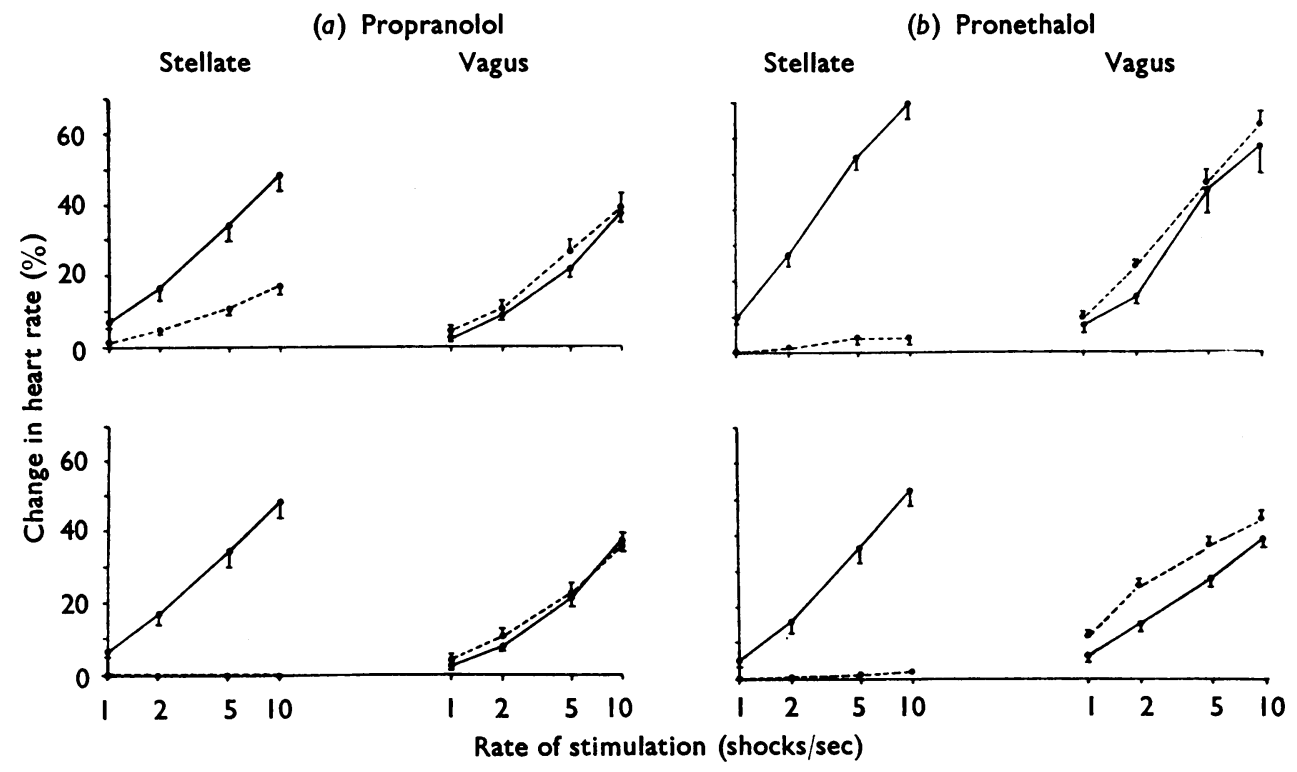

Fig. 6. Cats anaesthetized with chloralose. Changes in heart rate were produced by stimulation of the right stellate ganglion and the right vagus nerve before and after the intravenous infusion of (a) propranolol at 5 and $50 \mu \mathrm{g} / \mathrm{kg} / \mathrm{min}$, and $(b)$ pronethalol at 50 and $200 \mu \mathrm{g} / \mathrm{kg} / \mathrm{min}$. Continuous lines, responses before drug; interrupted lines, responses after drug. Vertical lines indicate standard errors.

\section{Pharmacological half-life of propranolol and pronethalol}

The pharmacological half-lives of propranolol and of pronethalol have been determined in conscious and in anaesthetized dogs and in conscious rabbits. In these experiments the increase in heart rate produced by the intravenous injection of isoprenaline $(0.2$ to $0.4 \mu \mathrm{g} / \mathrm{kg}$ ) was recorded before and at $10 \mathrm{~min}$ intervals after the intravenous injection of propranolol or pronethalol. The results of the experiments in conscious rabbits are shown in Fig. 7 ; propranolol and pronethalol were given at $0.4 \mathrm{mg} / \mathrm{kg}$ intravenously. The results are expressed as percentage block of the control tachycardia due to isoprenaline. In three rabbits isoprenaline alone was given, saline being administered at the time when propranolol or pronethalol would have been given. In these the changes in the isoprenaline tachycardia was less than $\pm 10 \%$ over a $3 \cdot \mathrm{hr}$ period. The half-lives for the block produced by propranolol in the four rabbits were $40,40,53$ and 60 min and for that produced by pronethalol in three rabbits were 36,40 and $45 \mathrm{~min}$. These results indicate 


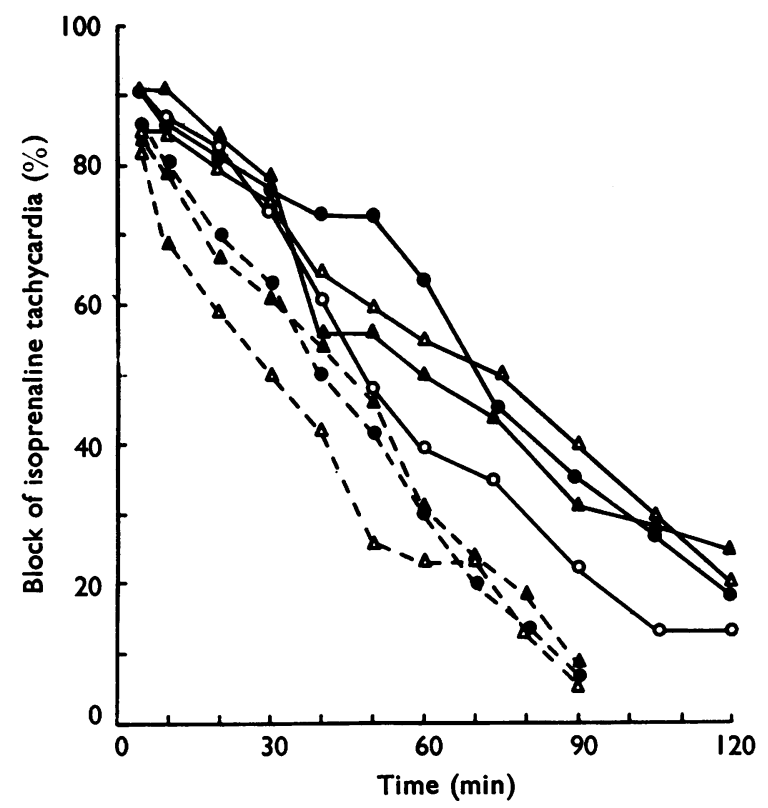

Fig. 7. Observations on conscious rabbits. Propranolol $(0.4 \mathrm{mg} / \mathrm{kg})$ and pronethalol $(0.4 \mathrm{mg} / \mathrm{kg})$ were given by intravenous injection at zero time. Their effect on the increase in heart rate produced by the intravenous injection of isoprenaline $(0.2 \mu \mathrm{g} / \mathrm{kg})$ is shown. Each set of symbols represent observations in a single rabbit. Continuous lines, observations after propranolol : interrupted lines, observations after pronethalol.

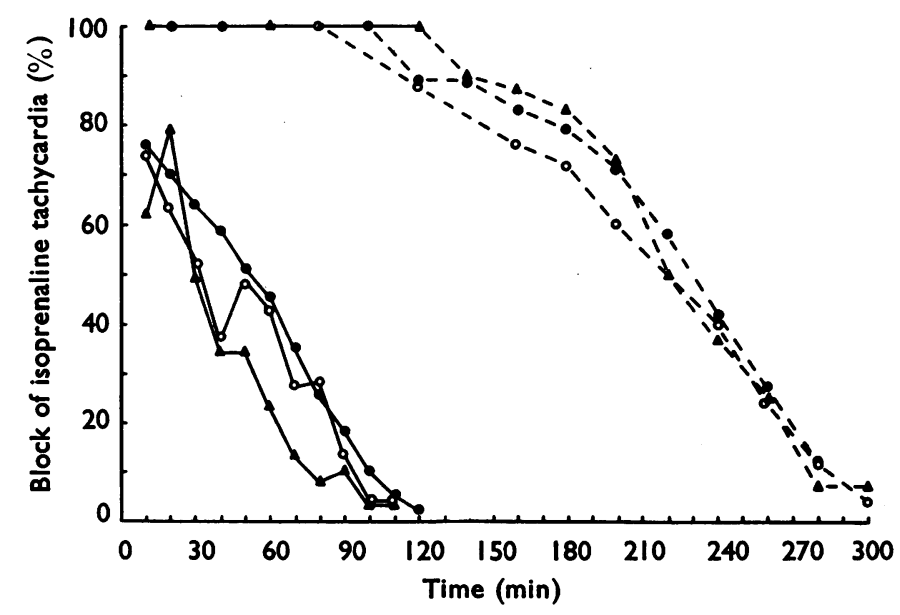

Fig. 8. Observations on conscious dogs. The effect of propranolol given by intravenous injection at zero time on the increase in heart rate produced by the intravenous injection of isoprenaline $(0.2 \mu \mathrm{g} / \mathrm{kg})$ is shown. Interrupted lines, propranolol $(0.8 \mathrm{mg} / \mathrm{kg})$; continuous lines, propranolol $(0.2 \mathrm{mg} / \mathrm{kg})$. Each set of symbols represents observations in a single dog. 
that in rabbits there is no marked difference in the pharmacological half-life of the two compounds. The pharmacological half-life of propranolol has been determined in the same way in six conscious and in four anaesthetized dogs. The results of the experiments in the conscious dogs are given in Fig. 8. After the intravenous injection of propranolol $(0.2 \mathrm{mg} / \mathrm{kg})$, the half-lives were 35,50 and $52 \mathrm{~min}$ in the three dogs. The intravenous injection of propranolol $(0.8 \mathrm{mg} / \mathrm{kg})$ produced complete blockade of the tachycardia due to isoprenaline for $100 \mathrm{~min}$. In these experiments the pharmacological half-life was determined when the block of the isoprenaline tachycardia was less than $75 \%$; the values obtained were 42,50 and $63 \mathrm{~min}$. The pharmacological half-lives of propranolol $(0.5 \mathrm{mg} / \mathrm{kg})$ in four dogs anaesthetized with pentobarbitone were $40,50,80$ and $90 \mathrm{~min}$.

\section{Metabolic half-life of propranolol and pronethalol}

The metabolic half-life of each compound was found by injecting 1 or $2 \mathrm{mg} / \mathrm{kg}$ of the salt intravenously into conscious and into anaesthetized dogs, conscious rabbits and anaesthetized cats. Arterial blood samples were withdrawn at regular intervals for estimation of the drug concentration. The results are given in Table 3. These show that there is no marked difference between the metabolic half-life of propranolol and that of pronethalol in these species.

TABLE 3

THE METABOLIC HALF-LIFES OF PROPRANOLOL AND PRONETHALOL IN DIFFERENT ANIMALS

\begin{tabular}{llccc} 
Preparation & Compound & $\begin{array}{c}\text { No. of } \\
\text { expts. }\end{array}$ & \multicolumn{2}{c}{ Metabolic half-life (min) } \\
\cline { 3 - 5 } $\begin{array}{c}\text { Conscious dog } \\
\text { Anaesthetized dog }\end{array}$ & $\begin{array}{l}\text { Propranolol } \\
\text { Propranolol }\end{array}$ & 4 & $48,46,46,32$ & Mean \\
& & 7 & $35,50,68,54$, & 41 \\
Conscious rabbit & Pronethalol & 3 & $45,40,40$ & 45 \\
Anaesthetized cat & Propranolol & 3 & $32,60,44$ & 49 \\
& Pronethalol & 3 & $60,66,70$ & 42 \\
& Propranolol & 4 & $39,33,42,62$ & 65 \\
& Pronethalol & 2 & 54,56 & 55
\end{tabular}

Tissue distribution of propranolol and prcnethalol

The tissue distributions of the compounds were determined in rabbits which were killed $1 \mathrm{hr}$ after the subcutaneous injection of propranolol or pronethalol $(10 \mathrm{mg} / \mathrm{kg})$. The results shown in Table 4, which were obtained from three rabbits for each compound, are expressed as the ratios of the tissue concentration of the drug to the simultaneously determined blood concentration.

TABLE 4

TISSUE DISTRIBUTIONS OF PRONETHALOL AND PROPRANOLOL IN RABBITS EXPRESSED AS A RATIO OF THE CONCENTRATION IN THE BLOOD

Values are means of three experiments

$\begin{array}{ccccccccccc}\text { Drug } & \text { Muscle } & \text { Kidney } & \text { Spleen } & \text { Uterus } & \text { Heart } & \text { Brain } & \text { Liver } & \text { Lung } & \text { Duodenum Fat } \\ \text { Pronethalol } & 7 & 109 & 210 & 23 & 35 & 117 & 4 & >100 & 18 & 1 \\ \text { Propranolol } & 6 & 90 & 134 & 27 & 44 & 47 & 2 & 250 & 21 & 7\end{array}$

\section{Acute toxicity}

The acute toxicities of propranolol and pronethalol after oral and intravenous administration have been determined in mice. Propranolol and pronethalol were each given to sixty mice by intravenous injection and to seventy mice by oral administration. The 
TABLE 5

ACUTE LD50 OF PROPRANOLOL AND PRONETHALOL IN MICE

Intravenous injections took $30 \mathrm{sec}$. The standard error was $\pm 5 \%$ for each mean intravenous LD50, and $\pm 9 \%$ for each mean oral LD50

\begin{tabular}{|c|c|c|c|c|c|}
\hline \multirow[b]{2}{*}{ Sex } & \multirow[b]{2}{*}{$\cdot$} & \multicolumn{2}{|c|}{ Intravenous LD50 for } & \multicolumn{2}{|c|}{ Oral LD50 for } \\
\hline & & $\begin{array}{c}\text { Propranolol } \\
(\mathrm{mg} / \mathrm{kg})\end{array}$ & $\begin{array}{c}\text { Pronethalol } \\
(\mathrm{mg} / \mathrm{kg})\end{array}$ & $\begin{array}{c}\text { Propranolol } \\
(\mathrm{mg} / \mathrm{kg})\end{array}$ & $\begin{array}{c}\text { Pronethalol } \\
(\mathbf{m g} / \mathbf{k g})\end{array}$ \\
\hline $\begin{array}{l}\text { Male } \\
\text { Female }\end{array}$ & & $\begin{array}{l}38 \cdot 4 \\
45 \cdot 3\end{array}$ & $\begin{array}{l}46 \cdot 3 \\
45 \cdot 3\end{array}$ & $\begin{array}{l}551 \\
471\end{array}$ & $\begin{array}{l}512 \\
587\end{array}$ \\
\hline
\end{tabular}

results are given in Table 5. There is no significant difference between the LD50s for the two compounds on oral administration. The LD50 for intravenous propranolol in male mice is less than the value in female mice and the values for pronethalol in male and female mice. Although this difference is significant it is not great enough to indicate a different action of propranolol in these mice.

\section{DISCUSSION}

In the work reported here no attempt has been made to show that propranolol is a sympathetic $\beta$-receptor antagonist effective at all possible sites. However, propranolol blocks the chronotropic effects of isoprenaline, adrenaline and stimulation of the stellate ganglion, and the peripheral vasodilator action of isoprenaline. It was previously shown to block the inotropic effect of isoprenaline in anaesthetized dogs (Black et al., 1964). These observations indicate that propranolol blocks the cardiovascular responses associated with sympathetic $\beta$-receptors.

In our work the intravenous infusion of propranolol into cats produced a fall in heart rate, while pronethalol in comparable blocking doses produced no change in rate. Pronethalol possesses intrinsic sympathomimetic activity (Barrett, 1965 ; Donald et al., 1964 ; Subbu, Flacke \& Seifen, 1964), although to a much lesser extent than does dichloroisoprenaline (Furchgott, 1959; Dresel, 1960). In the cat, if it is assumed that the fall in heart rate produced by propranolol is the result of blocking endogenous sympathetic activity to the heart, the absence of the fall in heart rate with pronethalol may be indicative of intrinsic sympathomimetic activity. This was confirmed in the experiments in the cats treated with syrosingopine to deplete noradrenaline stores (Orlans et al., 1960), as pronethalol was found to increase heart rate. Propranolol produced no change in rate as there was no sympathetic drive to block, indicating that it is devoid of intrinsic sympathomimetic activity under these circumstances.

The finding of Black \& Stephenson (1962) and Donald et al. (1964) that effective blocking doses of pronethalol in anaesthetized animals lowered arterial blood pressure has been confirmed in the present experiments. Propranolol, although blocking the hypotension due to isoprenaline to the same extent as pronethalol, did not effect resting diastolic pressure; the control diastolic pressure in the group of dogs given pronethalol was significantly higher than in the group that received propranolol, and statistical analysis showed that this difference did not influence the interpretation of the results. In other experiments using anaesthetized dogs the intravenous infusion or injection of propranolol in amounts greater than those used in the present experiments did not affect arterial pressure (Shanks, unpublished). These results suggest that the hypotensive action of pronethalol on intravenous administration into anaesthetized animals is not the result 
of blockade of $\beta$-receptors but may be another manifestation of its intrinsic sympathomimetic activity (Donald et al., 1964).

The present experiments have shown that the systemic administration of large amounts of pronethalol and propranolol completely antagonized the effects of sympathetic stimulation on the heart, but had no effect on the bradycardia produced by vagal stimulation. These findings suggest that the observations of James \& Nadeau (1964), who found that direct perfusion of the sinus node with pronethalol blocked both cardiac acceleration from adrenergic stimuli and cardiac inhibition from vagal stimulation, are only relevant for their own experimental preparation and that pronethalol and propranolol, unlike sympathetic $\alpha$-receptor blocking agents such as phenoxybenzamine (Benfey, 1962), do not block cholinergic stimuli.

While accurate potency ratios cannot be calculated from the results presented in this paper, it is clear that propranolol is a much more active compound than pronethalol. The difference in activity was seen in the experiments both in vitro and in vivo and for both chronotropic and inotropic effects (Black $e$ t al., 1964). The results for the pharmacological half-life of propranolol in conscious and in anaesthetized dogs and in conscious rabbits were similar to those for the metabolic half-life in the same species. Similar values were obtained for the pharmacological half-life of pronethalol in conscious rabbits and for the metabolic half-life in dogs, cats and rabbits. This evidence is consistent with the idea that propranolol has an increased affinity for $\beta$-receptors and that the activity of both compounds is directly related to the concentration in the blood.

Tissue distribution studies of the two compounds in rabbits show that the compounds are widely distributed in the body and that the patterns of distribution are similar. The highest concentrations were found in the lung, spleen and kidney. The concentration of pronethalol in the brain was higher than that of propranolol, whereas there was little variation in the amounts present in the heart.

The greater $\beta$-receptor blocking activity of propranolol is not reflected in enhanced nonspecific actions or carcinogenic activity. In mice the acute toxic effects of pronethalol were attributed to a nonspecific action on the central nervous system as the acute LD50 for the dextro- (inactive) and laevo- (active) isomers was the same as that for the racemate (Howe, 1963). That these toxic effects were not a consequence of $\beta$-receptor blockade is supported by the present results, which show that the acute toxic effects of pronethalol and propranolol are similar. The carcinogenic activity of pronethalol in mice does not appear to be the result of $\beta$-receptor blockade, as tumours did not occur in mice treated with large doses of propranolol for a long period (Alcock et al., 1965).

\section{SUMMARY}

1. Propranolol is a more active sympathetic $\beta$-receptor antagonist than pronethalol.

2. Propranolol is about ten- to twenty-times more active than pronethalol in antagonizing the increase in rate of the isolated right atrial strip of the guinea-pig produced by adrenaline, the tachycardia due to isoprenaline in anaesthetized cats, and the vasodepressor effects of isoprenaline in anaesthetized dogs.

3. Propranolol decreased resting heart rate in cats anaesthetized with chloralose; it was devoid of intrinsic sympathomimetic activity. 
4. Propranolol in amounts that antagonized the depressor response to isoprenaline in anaesthetized dogs did not reduce arterial pressure.

5. Propranolol in amounts that completely abolished the increase in heart rate produced by stimulation of the right stellate ganglion in anaesthetized cats did not affect the bradycardia produced by vagal stimulation.

6. The pharmacological and metabolic half-lives of propranolol and pronethalol were similar, being in the range 40 to $60 \mathrm{~min}$.

7. The LD50 of propranolol in mice after oral or intravenous administration was similar to that of pronethalol.

8. It is concluded that propranolol is a sympathetic $\beta$-receptor antagonist more active than pronethalol but devoid of intrinsic sympathomimetic activity.

The authors gratefully acknowledge the technical assistance of $\mathbf{M r}$ J. Carter, Mr D. Dunlop, Miss S. Thornhill and Miss D. Williams.

\section{REFERENCES}

ABboud, F. M., ECKSTEIN, J. W. \& Zimmerman, B. G. (1963). Effect of “ beta-receptor-blocking drugs " on venous and arterial responses to isoproterenol. Clin. Res., 11, 162.

AHLQUist, R. P. (1948). A study of the adrenotropic receptors. Amer. J. Physiol., 153, 586-600.

AHLQUIST, R. P. (1963). Beta adrenergic receptor blockade by naphthylisoproterenol. Fed. Proc., 22, 449.

ALCOCK, S. J., BAKER, S. B. DE C. \& TUCKER, M. J. (1965). A comparison of the carcinogenicity of pronethalol and propranolol in mice. Brit. med. J., in the press.

ALCOCK, S. J. \& Bond, P. A. (1964). Observations on the toxicity of Alderlin (pronethalol) in laboratory animals. Proc. Europ. Soc. Stud. Drug Toxicity, 4, 30-39.

Alleyne, G. A. O., Dickinson, C. J., Dornhorst, A. C., Fulton, R. M., Green, K. G., Hill, I. D., Hurst, P., Laurence, D. R., Pilkington, T., Prichard, B. N. C., Robinson, B. \& Rosenheim, M. L. (1963). Effect of pronethalol in angina pectoris. Brit. med. J., ii, 1226-1229.

APTHORP, G. H., Chamberlain, D. A. \& Hayward, G. W. (1964). The effects of sympathectomy on the electrocardiogram and effort tolerance in angina pectoris. Brit. Heart J., 26, 218-226.

BARRETT, A. M. (1965). The effects of some autonomic blocking agents on the heart rates of anaesthetized and pithed rats. Brit. J. Pharmacol., 25, 545-556.

BeNFEY, B. G. (1962). The effect of phenoxybenzamine on vagal inhibition of the heart. Canad. $J$. Biochem., 40, 1457-1459.

Bishop, J. M. \& SEgEL, N. (1963). The circulatory effects of intravenous pronethalol in man at rest and during exercise in the supine and upright positions. J. Physiol. (Lond.), 169, 112-114P.

Black, J. W., Crowther, A. F., Shanks, R. G., Smith, L. H. \& Dornhorst, A. C. (1964). A new adrenergic beta-receptor antagonist. Lancet, $\mathrm{i}, 1080-1081$.

Black, J. W. \& Stephenson, J. S. (1962). Pharmacology of a new adrenergic beta-receptor-blocking compound (nethalide). Lancet, ii, 311-314.

Chamberlain, D. A. \& Howard, J. (1964). The haemodynamic effects of $\beta$-sympathetic blockade. Brit. Heart J., 26, 213-217.

CohEn, J., EfFat, H., Goodwin, J. F., OAKLeY, C. M. \& STEINER, R. E. (1964). Hypertrophic obstructive cardiomyopathy. Brit. Heart J., 26, 16-32.

COTTEN, M. DE V. (1953). Circulatory changes affecting measurement of heart force in situ with strain gauge arches. Amer. J. Physiol., 174, 365-370.

DAvies, M. T. (1959). A universal buffer solution for use in ultra violet spectrophotometry. Analyst, 84 248-251.

Donald, D. E., Kvale, J. \& ShEPHERD, J. T. (1964). The effect of an adrenergic beta-receptor antagonist on the cardiovascular system of the dog. J. Pharmacol. exp. Ther., 143, 344-349.

DORNHORST, A. C. \& LAURENCE, D. R. (1963). Use of pronethalol in phaeochrome tumours. Brit. med.J., ii, $1250-1251$.

DORNHORST, A. C. \& RoBInson, B. F. (1962). Clinical pharmacology of a beta-adrenergic-blocking agent (nethalide). Lancet, ii, 314-316.

DRESEL, P. E. (1960). Blockade of some cardiac actions of adrenaline by dichloroisoproterenol. Canad.J. Biochem., 38, 375-381. 
EHRINGER, H. \& GöGEL, H. (1963). Zur Wirkung von Nethalide auf eine experimentell ausgelöste Myokardnekrose der Ratte. Naunyn-Schmiedeberg's Arch. exp. Path. Pharmak., 246, 47-48.

ERLIJ, D. \& MENDEZ, R. (1964). The modification of digitalis intoxication by excluding adrenergic influences on the heart. J. Pharmacol. exp. Ther., 144, 97-103.

FURCHGOTT, R. F. (1959). The receptors for epinephrine and norepinephrine. Pharmacol. Rev., 11, 429-442.

GRANDJEAN, T. \& RIVIER, J.-L. (1963). Utilisation d'un antagoniste des catecholamines (I.C.I. 38,174, "Alderlin") dans le traitement de quelques cas de troubles du rythme cardiaque. Schweiz. med. Wschr., 93, 1101-1104.

harrison, D. C., Braunwaid, E., Glick, G., Mason, D. T., Chidsey, C. A. \& Ross, J. (1964). Effect of beta adrenergic blockade on the circulation with particular reference to observations in patients with hypertrophic subaortic stenosis. Circulation, 29, 84-98.

Hess, J. M. \& Hampton, L. J. (1964). Prevention of epinephrine-halothane arrhythmias by adrenergic $\beta$-receptor blockade. Anesthesiology, 25, 101-102.

HowE, R. (1963). Structure activity relationships of some $\beta$-adrenergic blocking agents. Biochem. Pharmacol., 12, suppl. 85.

JAMES, T. N. \& NADEAU, R. A. (1964). The chronotropic and vagal-blocking actions of naphthylisoproterenol studied by direct perfusion of the sinus node. J. Pharmacol. exp. Ther., 143, 350-355.

JoHNSTONE, M. (1964). Beta-adrenergic blockade with pronethalol during anaesthesia. Brit. J. Anaesth., 36, 224-232.

KAKo, K., KRAYENBÜHL, H. P., LÜTHY, E. \& HEGGLIN, R. (1964). Cardiovascular effects of catecholamines in dogs before and after $\beta$-adrenergic blockade. Naunyn-Schmiedeberg's Arch. exp. Path. Pharmak., 246, 297-308.

LEVy, B. \& TozzI, S. (1963). The adrenergic receptive mechanism of the rat uterus. J. Pharmacol. exp. Ther., 142, 178-184.

Lowe, R. D. \& RoBINSON, B. F. (1964). Effect of differential adrenergic blockade on response of forearm blood flow to infused catecholamines. Clin. Sci., 26, 81-87.

LUM, B. K. B. \& KERMANI, M. H. (1963). Selective loss of response to alpha adrenergic agents following cold storage of the rabbit jejunum. Fed. Proc., 22, 449.

MCEWEN, L. M. (1956). The effect on the isolated rabbit heart of vagal stimulation and its modification by cocaine, hexamethonium and ouabain. J. Physiol. (Lond.), 131, 678-689.

MEesTeR, W. D., HARDMAN, H. F. \& BARBoriaK, J. J. (1963). Quantitative evaluation of nethalide (NET), dichloroisoproterenol (DCI) and $\mathrm{N}$-isopropylmethoxamine (IPM) as beta-receptor blocking agents in the isolated rabbit heart. Pharmaculogist, 5, 249.

MurRay, W. J., MCKNIGHT, R. L. \& Davis, D. A. (1963). Antagonism of hydrocarbon anaestheticepinephrine arrhythmias in dogs by nethalide, a dichloroisoproterenol analogue. Proc. Soc. exp. Biol. (N.Y.), 113, 439-441.

NAGASAKA, M., SCHAEPDRYVER, A. F. DE \& HEYMANS, C. (1964). The anti-adrenergic property of pethalide on the isolated guinea-pig lung. Arch. int. Pharmacodyn., 149, 232-236.

Orlans, F. B. H., Finger, K. F. \& BRODIE, B. B. (1960). Pharmacological consequences of the selective release of peripheral norepinephrine by syrosingopine (SU 3118). J. Pharmacol. exp. Ther., 128, 131-139.

Paget, G. E. (1963). Carcinogenic action of pronethalol. Brit. med. J., ii, 1266-1267.

PAYNe, J. P. \& SENFIEld, R. M. (1964). Pronethalol in treatment of ventricular arrhythmias. Brit. med.J., i, 603-604.

SCHILD, H. O. (1947). A new scale for the measurement of drug antagonism. Brit. J. Pharmacol., 2, 189-206.

SCHRÖDER, G. \& WERKö, L. (1964). Nethalide, a beta adrenergic blocking agent. Clin. Pharmacol. Ther., $5,159-173$.

Soman, P., Hardman, H. F. \& LuM, B. K. B. (1963). Antagonism of cardiac arrhythmias by nethalide. Pharmacologist, 5, 260.

STOCK, J. P. P. \& DALE, N. (1963). Beta-adrenergic receptor blockade in cardiac arrhythmias. Brit. med. J., ii, $1230-1233$.

Subbu, V. S. V., Flacke, W. \& Seifen, E. (1964). Adrenergic and $\beta$-blocking action of nethalide. Pharmacologist, 6, 165.

Vaughan Williams, E. M. \& Sekiya, A. (1963). Prevention of arrhythmias due to cardiac glyccsides by block of sympathetic $\beta$-receptors. Lancet, $\mathbf{i}, 420-421$. 